\title{
Apparition in The Turn of the Screw: Real or Schizophrenic Revelations? MoHammad Azizul HaQue
}

The apparitions in Henry James' The Turn of the Screw have perplexed quite a good number of readers for their very mysterious interventions. The novel has provoked great discussion and debate, as it concerns the ongoing question of the existence of the supernatural. The Turn of the Screw tells the story of a young governess, sent to the secluded and mysterious estate of Bly to supervise two young children, Miles and Flora, her employer's nephew and niece. The housekeeper, Mrs. Grose, seems to be the only adult the governess develops a relationship with and is used by James to create an ambiguity concerning the truth of the happenings of Bly. This article aims at a study of the supernatural and seeks for an understanding of this ambiguity left unsolved by the writer.

Having been persuaded by the charm of her employer to accept the job, the governess arrives at the house only to be greeted by the strange appearances of apparitions she concludes to be former employees of the house, Miss Jessel, the governess, and Peter Quint, the master's valet. While the children deny the existence of such ghosts, the governess' vivid sightings of the apparitions and the children's development of adult-like behavior support that the spirits of Miss Jessel and Quint are indeed real, having returned from death to possess the souls of Miles and Flora.

The vivid description of her sightings of the ghosts of Peter Quint and Miss Jessel by the governess tends us to believe the reality of what she has seen. After having sighted the male apparition for the second time the governess relays both incidents to Mrs. Grose, accurate enough for the housekeeper to recognize the description. The governess recalls, "He has red hair, very red, close-curling, and a pale face, long in shape, with straight good features and little rather queer whiskers that are as red as his hair. His eyebrows are somehow darker; they look particularly arched ... his eyes are sharp, strange ... his mouth's wide, and his lips are thin, and except for his little whiskers he's quite clean-shaven" (James 29). From this sole 
description Mrs. Grose is able to identify the man as Peter Quint, whom she explains to be the master's former valet who has died. Since the governess has never before seen or heard of Peter Quint, the only source of her memory is the apparition itself meaning that it must in fact exist. Again when the governess sights the ghost of the former governess, Miss Jessel, across the lake she tells Mrs. Grose it was "a figure of quite as unmistakable horror and evil: a woman in black, pale and dreadful-with such an air also, and such a face" (James 37). While it was the governess who introduces the idea that the second apparition is Miss Jessel, Mrs. Grose accepts the conclusion, displaying the ease in which the housekeeper is able to be influenced.

It is for her easily persuaded character that James is able to create the ambiguity through Mrs. Grose in The Turn of the Screw. Upon the governess' questioning concerning Peter Quint's relationship with Miles, Mrs. Grose reveals that Quint was "too free with every one" (James 32), especially Miles. This comment introduces the idea that his "freedom" was of a sexual manner, creating an unnatural emotional relationship between Miles and Flora and Quint. Through this relationship James establishes a connection between the innocence and corruption co-existent within Miles and Flora. Upon the governess' first view of Flora she describes her as "a creature too charming not to make it a great fortune to have to do with her" (James 10), full of "angelic beauty" (James 10) and Miles as "incredibly beautiful" (James 17). These words are the culmination of everything appearing to be perfect and innocent, just as the governess sees the children as beings. After receiving the letter from Miles school saying he has been dismissed, the governess describes him in accordance with his actions as "an injury to his poor little innocent mates" (James 14) and his doings at a level "to contaminate" and "corrupt" others (James 15). Such words are harsh and associated with an opposite supernatural realm as "angelic," associating the children to the corruption of adulthood, elements Mrs. Grose has already revealed were present in Miss Jessel and Peter Quint.

As the story progresses the governess discovers an ongoing relationship between Miles and Quint, Flora and Miss Jessel, which shows the children's apparent knowledge of the ghost's existence. After seeing the ghost of Peter Quint at the window the governess discovers that he was intently looking for Miles. "'He was 
looking for little Miles.' A portentous clearness now possessed me. 'That's whom he was looking for'" (James 31). Again upon seeing Miss Jessel's ghost across the pond the governess tells Mrs. Grose that the apparition had "fixed the child ... with such awful eyes ... with a determination-indescribable. With a kind of fury of intention" (James 38). These two incidents directly connect the children to the reason Quint and Miss Jessel have returned to Bly, to possess and live through Miles and Flora. The governess also concludes that the children are aware of their possessors and are deliberately trying to conceal Quint and Jessel's existence. At the pond, for instance, Flora deliberately turns her back on the apparition, consciously ignoring its existence, then later denies to the governess that it had in fact existed. It is for this reason the governess takes up her job with a new determination to save the "lost" children (James 40). Again when the governess finds Flora awake late at night staring down through her window at Miles who was down on the lawn "motionless and as if fascinated ... looking ... at something that was apparently above me" (James 53). Later on Miles explains he was simply trying to cause some excitement and make the governess think him bad. It is more accurately concluded however that he was not himself, but, in a trance communicating with Peter Quint. Even at the end, Miles ambiguously admits the existence of the apparitions as, he and the governess left alone by the other servants, the governess proclaims they were not "absolutely" alone (referring to the ghosts of Quint and Jessel) (James 95). In response Miles admits, "Of course we've the others" (James 95) hinting that he is aware of Quint's and Jessel's supernatural existence. As the time progresses, however, Miles and Flora show further and more intense evidence of being possessed and thus make the revelation of the governess more difficult to conclude with.

Miles' and Flora's behavior in the later chapters of the story become more adultlike and hostile toward the governess as her knowledge of the apparitions expands, displaying the evident reality that they are indeed possessed by the spirits of Quint and Jessel whom the governess has identified. Beginning with Miles and Flora's language toward the governess, referring to her as "dear" (James 76), their general behavior becomes less like children and more corrupt. At the governess' second sighting of Miss Jessel across the lake, she points out to both Flora and Mrs. Grose 
the existence of the apparition. However, Flora "without a convulsion of her small pink face, not even feign to glance in the direction of the prodigy I announced, but only, instead of that, turn[ed] at me an expression of hard still gravity, an expression absolutely new and unprecedented and that appeared to read and accuse and judge me" (James 84).

Other than following what the governess is pointing out, Flora turns on the governess, hysterical at her accusations, full of fear that Miss Jessel's existence will be revealed. At this point Flora is not the innocent child of "angelic beauty" the governess had first perceived (James 10) but instead "an old, old woman", possessed by the spirit of her former governess (James 84). Even Miles' actions at school and the reason for his expulsion, which he later reveals was because he "said things . . . [to] those he liked" (James 101), suggesting again his words were too adult, or "corrupt" for the school's discipline (James 15). At the very end of the book, following Miles' confession of saying "these things," the governess final succeeds in dispossessing the children of Quint and Jessel's influence. While being alone with Miles the governess points again at the ghost of Peter Quint. Miles responds, "Peter Quint- you devil . . . Where" (James 103). His last word pathetically reveals to the governess that the children have been unwillingly possessed by the spirits as Miles refers to Quint as "devil" and does not recognize his presence. "He has lost you forever" (James 103), the governess exclaims, having dispossessed Miles by forcing his recognition of Quint. However left by the soul of Quint, Miles is overcome by his corruption and dies. "We were alone with the quiet day, and his little heart, dispossessed, had stopped" (James 103). By using the term "dispossessed" it is implied that Miles was in fact once possessed, concluding the ghosts of Quint and Jessel in fact exist and is not perhaps just the imagination of the governess.

While it is true that the governess has been isolated from normal social interactions by her job at Bly, the vivid details she is able to extract from her visions without any help from those who actually knew Quint and Jessel might conclude that she, in fact, saw these apparitions. Even the children's disturbing, adult-like behaviour-- especially at the mention of their former caretakers-- display evidence that the souls of Quint and Jessel have indeed come back to carry out their 
malicious purpose through Miles and Flora. The governess, increasingly devoted to liberating the children, is overcome by the influence these spirits hold over Miles and Flora and succeeds only in driving them away and eventually killing Miles! It is through the governess' struggle that James creates the conclusion that the power of Quint and Jessel is too strong to simply be an imagination of even a scared and delusional young girl.

The essential question that tantalizes the readers in general is whether the ghosts of Peter Quint and Miss Jessel are real. They seem to appear only to the governess and she is the only one who admits seeing them. F. W. H. Myers recognized apparitions as a manifestation of persistent personal energy, --or an indication that some kind of force is being exercised after death which is in some way connected to a person previously known on earth. This fits the story perfectly for the ghosts appear to be nothing, just a "manifestation." The governess swears that Miles and Flora see the ghosts too, but they refuse to admit it. She says, "whatever I had seen, Miles and Flora saw more - things terrible and unguessable and that sprang from dreadful passages of intercourse in the past." (James 53) They are scared or intimidated. Some of the places the governess appears show many parallels to the sightings of the ghosts as well. The governess sees Quint in the glass door and up on the tower, a place where Mrs. Grose notices the governess. And the governess sees Miss Jessel sitting at her desk. She recalls, "In the presence of what I saw I reeled back upon resistance. Seated at my own table in the clear noonday light I saw a person ..." (James 59). When she sees the ghosts, it's like a mirror image. And mirrors ultimately just show the own self in full and obvious form. When the governess sees Miss Jessel across the lake, it could be her mirror image reflected in her mind. "Miss Jessel stood before us on the opposite bank ..." (James 71) the governess recalled. "Where on earth do you see anything?" replied Mrs. Grose (James 72). In the end, neither the governess nor we, the readers, are certain that these ghosts are out to get the children. Being the one who sees them, the governess might actually be the victim.

It becomes more obvious when the Governess expresses her deeply rooted desire in these lines: "Someone would appear there at the turn of the path and would stand before and smile and approve. I didn't ask more than that - I only asked that 
he should know." As she amuses herself with the idea that he might show up just to please her, she is suddenly amazed that, "He did stand there! - but high up, beyond the lawn and at the very top of the tower to which . . . little Flora had conducted me." Having an obsession the young lady finally tends to see the physical manifestations of her visions. One night, by candle-light, she sits to read Henry Fielding's Amelia. Fielding's symbolic novel foreshadows the governess's neurotic mind, who like the heroine suffers a spiritual crisis. The governess finds herself on similar grounds to the heroine, who, likewise, is a protector of two children. The heroine awaits her imprisoned husband, and the governess waits for her master too.

A modern reader may simply view this book dealing with psycho-neurotic problem of the governess which finally results in the presence of the supernatural beings. An inquisitive reading may prove that the ghost of Miss Jessel or Peter Quint is always welcomed because the person who witnesses their presence wants them to interfere in her crises and guide her ahead. Her stagnant life might be fueled by the dreamy presence of the apparitions. She seems to be obsessed with the manly presence of her employer and is sick of her loneliness. She wants to convince her unseen employer which might have resulted in schizophrenic revelations. Her fixations and the tender age might contribute to such complications. Famous psychiatrist Dr. Dhayasree views that sexual desires get gratified through dreamy revelations particularly at tender age and such things can even be analyzed through Freud's concept of expositions. According to Dr. Dhayasree, a person experiencing schizophrenia is typically characterized as demonstrating disorganized thinking, and as experiencing delusions or hallucinations. Schizophrenia, he says, is most commonly diagnosed during late adolescence or early adulthood suggesting that it is often the end process of childhood and adolescent development. Poor peer engagement and immaturity or unpopularity may lead to schizophrenia at this stage. Thus the "red hair", "straight good features", "whiskers as red as his hairs" and "arched eye brows" (James 29) are all psycho-sexual icons to the young governess who might have tried to find an outlet at a level beyond dreamy gratification, which are basically nothing but the extreme forms of schizophrenic revelations. A thorough analysis of the causes of 
schizophrenia may discover the unfulfilled sexual desires of the patient. Thus the governess can also be viewed as an unreliable narrator, either neurotic or insane; and the children either uncorrupted or corrupted by the treatment of the governess herself. Such studies would unearth the governess as a neurotic spinster whose repressed passion for her employer, the children's bachelor uncle, must have caused her to hallucinate. So, the novella since its publication in 1898 inspired a variety of critical interpretations and is not, of course, a conventional ghost story. The reality of ghosts, the sanity of the governess and the possible corruption of the children really have served the purpose of the novelist to make the reading ambiguous. So, any narrow interpretation of the text would not be exclusively correct, rather the tension created by the reciprocation of all these facts on both sides can be successfully supported by the text.

\section{Work Cited}

James, Henry. The Turn of the Screw. New York: New American Library, 1962. Print.

\section{References}

Dhanyasree M. “Suppressed Sexual Feelings and Schizophrenia.” Psychosexual Analysis. 2007. Web. 16 April 2011. <http:/ / living.oneindia.in/search.html >

Rictor, Norton. "Henry James's The Turn of the Screw", Gay History and Literature. 1971, 1999. Web. 18 April 2011. <http://rictornorton.co.uk/henjames.html>.

Samuels, Charles T. The Ambiguity of Henry James. Urbana: University of Illinois Press, 1971. Print. 